\title{
To What Extent Does Information and Communication Technology Support Inclusion in Education of Students with Learning Difficulties?
}

\author{
Terje Mølster*, Kari Nes \\ Inland Norway University of Applied Sciences, Norway
}

Copyright(C2018 by authors, all rights reserved. Authors agree that this article remains permanently open access under the terms of the Creative Commons Attribution License 4.0 International License

\begin{abstract}
The main intention of this study is to explore the relationship between information and communication technology (ICT) and inclusion. The target group is students who are conceived as having learning difficulties or special educational needs. To illuminate this issue, we draw on data collected in a recent national research project about the quality of special education in regular schools in Norway, the "SPEED project". One of the results is that ICT use among students with learning difficulty is more frequent than among average students, but not as widespread as you would expect, considering the alleged affordances of ICT for these students.
\end{abstract}

Keywords ICT, Learning Difficulties, Special Educational Needs, Inclusive Education, the SPEED Project

\section{Introduction}

\subsection{Context of the Research}

Ninety-six percent of all Norwegian learners aged 6-16 attend the common, free mainstream school, run by the local educational authorities. After the 1975 legislation reform, no children, even if they for instance are disabled, can be denied access to the local school; the new Act of Education covered all children. In the wake of the reform, the state special schools eventually closed down. A few local or private special schools exist, however. Hence, in principle, the common model is that disabled and non-disabled students, girls and boys and high and low achievers from diverse sociocultural backgrounds attend class together ${ }^{1}$. There is no permanent streaming according to ability. All learners are to receive differentiated and adapted instruction in the local school. Very few $(0.6 \%)$ are in special schools or special units in ordinary schools, and $3.6 \%$ attend private schools (1). The legislation ensures children with disabilities or other identified special educational needs (SEN) rights to special education or other adapted support in the schools where they are. Parallel rights exist for bilingual learners. The indigenous population, the Sámi, have their own syllabus in the Sámi language. Deaf children have a right to be taught in sign language (2).

While special schools are very few after the state special schools closed down ${ }^{2}$, special education is a right in all schools for those in need of it. The right to special education is non-categorical; it is intended to ensure adapted and equitable education for persons who do not, or cannot, gain satisfactory benefits from the regular teaching (Education Act §5-1). Through an expert assessment procedure ("statementing"), it is determined whether the students in question are entitled to special education and hence additional resourcing. Special education is offered to an average of about $8 \%$ of the students. Part-time special education within, or in connection with, ordinary classes is the most common organization of the special educational program (3). In addition to students with a disability, the group identified as having SEN consists of students with dyslexia or problems in the school subjects and students with behavioral problems. But, according to the teachers in the SPEED project, there are about twice as many students with learning difficulties in Norwegian schools who are not referred to special education (4).

1 The number of students in the state special schools never exceeded $1 \%$ of all students (Haug 2014). These schools closed down in the early nineties.

2 Many of the state special schools were turned into competency centers to support local schools. 
The extent of special education lessons offered varies from just several per week to most lessons throughout the week. For the rest of the lessons, the student follows the ordinary program of the class. The intention is to offer special education in the regular classroom, but an increase in the use of pull-out solutions and special classes is registered (5). All learners, with or without SEN, are supposed to be in a learning environment characterized by adapted education, meant to provide equal opportunities in the school for all, "regardless of abilities and aptitudes, age, gender, skin colour, sexual orientation, social background, religious or ethnic background, place of residence, family education or family finances" (6). Special education is seen as part of the adapted education.

What about ICT in this picture? In Norwegian schools, a student's ability to make use of information and communication technology is seen as one of five basic skills, along with reading and writing etc. (7). These basic skills are incorporated into the syllabuses for all subjects. Investments in digital technology have been numerous, and after our study was done, an increasing number of schools have bought tablets or computers to all first-year students. The effect of increased access to these devices is still unknown, but has the potential to support inclusion.

\subsection{Research Questions}

The main intention with this study is to explore the relationship between ICT and inclusion for students who are seen to have some sort of learning difficulty.

Our specific research questions are:

To what extent is ICT in any form used by students with learning difficulties?

To what extent does the use of ICT support inclusion for students with identified special educational needs?

The notion of learning difficulties is used in a broad sense, referring to any kind of individual obstacles to learning, as identified by the teacher, including, for instance, major disabilities as well as mild literacy or behavioral problems. Neurologically based learning disabilities are part of the term, the way it is used here (8). Some of the students with learning difficulties are referred to special education, but the majority of them are not, as we have seen above. For that reason our inquiry, in addition to looking into education for students with a statement of special educational needs, includes other students with difficulties as well.

\subsection{Theoretical Framework}

In this passage, we briefly introduce a general understanding of inclusion in education, linked to the specific part played by ICT in inclusion.

Inclusion is not a state; it is a process (cf (9)). Developing inclusion is about continuous efforts to increase and develop inclusive cultures, policies and practices in education. "Developing learning and participation in schools" is the subtitle of the Index for Inclusion, indicating how inclusion is framed in that book (10). Inclusion is not reduced to a question only of where teaching takes place. By inclusion in this study we refer to the necessity for all learners to develop their learning potential as fully as possible, belonging to a learning community and to a social and cultural community. Inclusion is physical, social and psychological, but also related to learning benefit, in other words not limited to physical or social factors only (11). These aspects are captured in seeing the development of learning as well as of participation as basic pillars of inclusion in education (10). Learning is in this study mainly seen as academic benefit, and participation as the social and psychological part of inclusion. Consequently, identifying and reducing barriers to learning and participation becomes the educational challenge.

The barriers are not primarily seen to be inherent in the child; they are rather seen as parts of the learning environment, such as teaching and learning methods and materials. The materials, for instance, may function as barriers to learning and participation for a specific student with literacy problems, or they can support it. An inclusive school aims at identifying such barriers, as well as acquiring the resources to address and remove the barriers. In our case, how can the use of ICT help to overcome barriers to learning and participation for students with SEN? We ask whether and how ICT-related pedagogy is supporting the development of learning and participation, i.e. increasing inclusion in education. Pedagogy can be defined as "what one needs to know, and the skills one needs to command, in order to make and justify the many different kinds of decisions of which teaching is constituted" (12). Pedagogy then includes knowledge and skills concerning children and their learning.

What are the affordances of ICT in teaching and learning related to students who struggle in school? According to Edyburn, Rao, and Hariharan (13), "Technology is often viewed as a promising intervention for diverse students to: a) gain access to the curriculum, (b) foster engagement, and (c) improve educational outcomes" (p. 357). The notion "diverse students" as used by these authors, includes students (14) with disabilities or other problems that may hamper learning, in addition to, for instance, students with an immigrant background. The authors highlight two common approaches associated with technology for diverse learners: assistive technology and universal design for learning.

Scholars also claim that ICT has the potential to promote inclusive education (15-19). Florian (17) states that "the use of ICT in responding to special educational needs opens new opportunities for participation and inclusion in the culture, curricula and communities of school" (p. 9). She argues that technology can compensate for differences among learners and create conditions for equal opportunity 
to learn and equal access to the curriculum for all. Abbott (18) has introduced the term e-inclusion, or digital inclusion, for the use of digital technologies to enable inclusive learning practices. Abbott suggests three categories of ICT usage for e-inclusion: Technology can be used 1) to train or rehearse 2) to assist learning, and 3) to enable learning. The first category represents the traditional use of ICT, such as software, for drill and practice for individual learners. The second category refers to assistive technology, which is normally used to compensate for physical disability or difficulty. While the first two approaches seem to put more emphasis on technology than learning, the last category gives technology a more modest but complex role in e-inclusion. Abbott argues that using technology to enable learning "foregrounds the need to pay attention to the role of teachers, and others, in creating the conditions within which digital technologies can be appropriately and effectively used to support e-inclusive practices" (p. 20).

\subsection{Previous Research}

The belief that ICT in education enhances learning and participation for all is widespread.

Research on the relationship between use of ICT and students' learning shows contradictory findings. Despite huge investments in technology, we lack clear indications that ICT actually promotes learning in school, when looking at the broad picture. When it comes to special education, the situation is more or less the same as for students in general, despite the existence of useful tools and software for students with various learning difficulties (16). However, there is evidence from Norway and elsewhere that students who use such tools can improve their learning outcome, for instance dyslexic students using adequate technology being able to overcome some of the barriers they experience (20). For persons with impairments, various digital devices can facilitate learning and compensate for their loss to some extent, if they have access and competent support, as put by the World Health Organization:

Assistive devices and technologies such as wheelchairs, prostheses, mobility aids, hearing aids, visual aids and specialized computer software and hardware increase mobility, hearing, vision and communication capacities. With the aid of these technologies, people with a loss in functioning are able to enhance their abilities, and are hence better able to live independently and participate in their societies. (WHO 2014) (21).

However, research on the use/usability of ICT for students with disability is practically non-existent, both in Norway and internationally (22). Based on the little research that exists, we can state that although digital technology has opened new opportunities for participation and learning, it seems that schools thus far have not been able to exploit digital technology to achieve more inclusive education $(16,22,23)$. But, Norwegian teachers do think favorably about ICT, for instance the majority of Norwegian teachers in the $7^{\text {th }}$ and $9^{\text {th }}$ grades agree that the use of ICT promotes reading, writing and collaboration. More than $80 \%$ agree that the use of ICT facilitates differentiated teaching (24). However, the bi-annual Monitor evaluation reports from the ICT center do not study "the use of ICT for inclusion," understood as inclusive settings for students with disabilities/special needs.

ICT is not only treasured for its compensatory value in education, but, as indicated by the WHO above, through this technology opportunities to participate in society are increased. Barriers to participation are removed or reduced. Already from the 1960s and onward it has been claimed that technology helps to increase participation and inclusion for learners with disabilities, in and out of school $(16,25,26)$.

Using new technology may also have negative effects. Some learners receiving special education feel stigmatized when using technical aids that are designed for disabled people $(27,28)$. According to Söderström (22), these learners therefore prefer using the same technology as the rest of the class.

In a Danish qualitative study, Svendsen (29) has tested a pedagogical design focusing on four students with literacy difficulties using reading and writing technology. The design had two objectives: to strengthen students' development of independent technology-based reading and writing strategies and promote the students' inclusion in general. The study indicates that there is a positive relationship between inclusion and learning outcomes. The two students who are fully socially and physically included are also the two students who develop the most technology-based strategies. The opposite goes for the other two students. The test showed that the pedagogy had an impact on the students' inclusion physically, socially and psychologically, as well as learning outcome. It appears that the computer as a primary artefact has an impact on the students' ability to cooperate and participate. Other issues influencing inclusion are whether students' use of reading and writing technology is integrated into the planning of teaching, and whether teachers have the time and support needed to carry out the planned design.

\section{Methods and Materials}

\subsection{The SPEED Project - About the Quality of Special Education}

As previously mentioned, our study is part of the SPEED project. This research project, which was funded by the Norwegian Research Council, looked into the quality of 
special education in primary and lower secondary education in Norway. Data about whole cohorts of children at the schools in question were also collected, not only about those receiving special education. A range of methods have been used. Children as well as their teachers and parents are informants.

The present article refers to survey data from students and teachers as well as classroom observations and interviews. Data collection mainly took place in 20132014. The sample in the survey is 4 cohorts of children (with and without special education) between 10 and 15 years old and their teachers. They represent all schools in 16 municipalities across southern Norway. The response rate was $80 \%$ for students and $73 \%$ for class teachers (30). The number of informants $(\mathrm{N})$ differs between the variables and will be shown in the results tables.

\subsection{Survey. Indicators of Inclusion and ICT Use}

Seeing inclusive education as being about developing learning and participation in schools, we have chosen indicators of learning and participation to see how the students and their teachers experience the situation. In addition, students were asked about their ICT use. The questions used in the digital survey were selected from national and international instruments that are proven sufficiently reliable and valid; see the references in the table below. Five factors were constructed: "social relations», "social isolation", "engagement", "academic achievement" and "total use of ICT". The construction of factors meets the statistical demands of scale constructions, i.e. high Cronbach's alfa and medium inter-item correlation (30).

Table 1. Operationalization of indicators in the survey

\begin{tabular}{|c|c|c|c|c|c|}
\hline $\begin{array}{c}\text { Infor- } \\
\text { mants }\end{array}$ & $\begin{array}{c}\text { Inclusion as developing } \\
\text { participation }\end{array}$ & $\begin{array}{c}\text { Sources for operationalization } \\
\text { of indicators }\end{array}$ & $\begin{array}{c}\text { Inclusion as } \\
\text { developing } \\
\text { learning }\end{array}$ & $\begin{array}{c}\text { The extent of } \\
\text { ICT use }\end{array}$ & $\begin{array}{c}\text { Sources for operationalization } \\
\text { of indicators }\end{array}$ \\
\hline Students & $\begin{array}{c}\text { Social relations } \\
\text { (10 questions, see below) } \\
\text { Social isolation } \\
(3 \text { questions, see below) }\end{array}$ & $\begin{array}{c}\text { Eccles \& Midgley (31), Eccles } \\
\text { al (32), Moos \& Trickett (33), } \\
\text { Ogden (34), Nordahl \& Sørlie } \\
\text { (35), Nordahl (36, 37), } \\
\text { Sørlie \& Nordahl (38) }\end{array}$ & $\begin{array}{c}\text { Total use of } \\
\text { ICT } \\
\text { (7 questions, } \\
\text { see below) }\end{array}$ & $\begin{array}{c}\text { Hatlevik, Egeberg, } \\
\text { Gudmunds-dottir, Loftsgarden } \\
\& \text { Loi (39) }\end{array}$ \\
\hline $\begin{array}{c}\text { Class } \\
\text { teachers }\end{array}$ & & $\begin{array}{c}\text { Engagement } \\
(4 \text { questions, see } \\
\text { below) } \\
\text { Academic } \\
\text { achievement } \\
(3 \text { questions, see } \\
\text { below) }\end{array}$ & & Skaalvik (40) \\
\hline
\end{tabular}

Questions in the factor «social relations» (student replies)

Social relations in school are about the children as well as teachers and other adults, but here our focus is on the peer relations, the scale being from totally agree (1) to totally disagree (4):

- If someone is having problems, classmates will help

- If someone is exposed to injustice, classmates will help

- The students in this class know each other well

- The students in this class are friends

- Some students in this class do not go well together

- I have become friendly with many students in this class

- In this class you are accepted even if you are not as clever as/ differ from others

- My classmates teave me in peace

- My classmates like me

- I do not get along so well with some of the students in class

Questions in the factor "social isolation" (student replies)

Social isolation was operationalized in three questions, asking the children to tick off on a scale from 1 (never) to very often (5):

- I feel lonely at school

- I am sad at school

- $\quad$ During breaks between lessons, I am with other students 


\section{Questions in the factor "engagement" (teacher replies)}

Class teachers regarded on a scale from 1 (very high) to

5 (very low) the student's

- motivation to succeed in school

- ability level compared to others in the class

- $\quad$ interest in learning in the lessons

- efforts during lessons

Questions in the factor "academic achievement" (teacher replies)

Class teachers were asked to assess the academic achievement of the student on a scale from 1 (very low) to 6 (very high) in the subjects Norwegian, mathematics and English.

Questions in the factor "total use of ICT" (student replies)

The following questions were put to the students about how often they use ICT in their schoolwork. It was made clear for the informants that the notion "computer" includes artefacts like PCs, Macs, tablets, iPads, and mobile phones. All variables have a nominal scale ranging from 1 indicating the lowest level of ICT use to 5 indicating the highest level (1 Never, 2 Several times a month, 3 Once a week, 4 Several times a week and 5 Daily).

- How often do you use computers in the subject Norwegian?

- How often do you use computers in the subject mathematics?

- How often do you use computers when presenting for the class?

- How often do you use computers to write assignments?

- How often do you use computers to take notes?

- How often do you use computers for collaboration?

- How often do you use computers to communicate with the teacher?

Analyses

The statistical analyses that were carried out include factor and reliability analyses with satisfactory results, in addition to analyses of frequency and variance (30). In the analyses, we have tried to find links between the use of ICT and indicators of inclusion. For ICT use, we have constructed two groups of students - the high-frequency users and the low-frequency users - to study possible differences between high and low usage of ICT. By using the principal component analysis in SPSS, we found that the seven questions on ICT use can be reduced to one factor representing students' use of ICT in school. The factor, Total Use of ICT, is computed as the sum of scores on each of the underlying questions. Total Use of ICT ranges from 7 (if the student has scored 1 in all seven questions) to 35 (if the student has scored 5 in all the questions). According to our definition, students scoring 21 or higher on the Total Use of ICT belong to the group of high-frequency users, while students scoring less than 21 belong to the group of low-frequency users.
In the analyses we also compare groups of students with different learning difficulties. In the survey the class teacher answered for each of the students in his/her class, including ticking off on a list of difficulties the student might have ${ }^{3}$.

In some of the tables with statistical comparison of groups, we use the PISA scale where the overall average is set at 500 points, and one standard deviation (SD) equals 100 points. Differences (effect size) of 0.4 SD (40 points in the table) or more are often regarded as significant differences. For instance, in table 2 below we see that most groups of students with SEN use ICT more than the average score of 500, and definitely more than their peers with no difficulties (score 492). But most differences are relatively small; only for students with reading and writing difficulties the difference is significant (score 542), i.e. more than 40 points.

\subsection{Classroom Observations and Interviews}

For the classroom observations, an instrument based on the "Time-Sample Measures of Behaviour" approach was developed $(42,43)$. The target of the observations was students formally identified as having special educational needs (SEN) according to $\S 5.1$ in the Education Act, hereafter called "students with SEN." They were taking part in special education lessons in or out of their regular class, usually in a part-time special education program. The student was observed when participating in special education as well as in regular lessons. Every 5 minutes during one whole day at school, the observer ticked off the actual activity the student was displaying or the situation (s)he was in. The categories were predefined. The age of students was between 11 and 15 . A total of 164 students in 25 schools were observed. Short interviews were also made of the observed students and their teachers.

\section{Results}

\subsection{Introduction to Results}

The results are based on quantitative data (survey) and qualitative data that have been quantified. In the survey, the class teacher answered for each of the students in his/her class, including ticking off on a list of difficulties the student might have. In total, $24.3 \%$ of the students were

3 In this project we have defined the following nine categories of learning difficulties or disabilities: Hearing impairments, visual impairments, ADHD-diagnosis, behavioral problems (without ADHD), reading and writing difficulties (students with literacy difficulties but believed to be within normal intellectual level), learning difficulties in mathematics (students having difficulties in mathematics but believed to be within normal intellectual level), other learning difficulties (students having academic difficulties but believed to be within normal intellectual level), general learning disabilities (students with problems in many subjects and not believed to be within the normal intellectual level) and other difficulties (like motor difficulties, special health problems, language difficulties (but not being a second language learner)). 
seen by their teachers to have difficulties of some sort. Out of these students less than $1 / 3$ are referred to special education $(7.1 \%$ of all students), most of them just a few hours per week. The tables below refer to students receiving special education and sometimes to the bigger group of students with different learning difficulties. Special education is the main formal system for addressing students' problems in schools, and the overarching aim of the SPEED project has been to look into the quality of this system. Why some students with difficulties are referred to special education and others are not is often unclear. This is in itself an interesting issue, but beyond the scope of this article (cf (44)).
In the text below, the figures are commented. Even some additional findings that are not in the tables are included in the text, in order to nuance the picture. In the figures adaptations were done for inverted questions, so that high scores always mean the most desirable option.

\subsection{The Extent of ICT Use}

For a start, we wanted to determine whether there were variations in ICT use between different groups of students who were seen by their class teachers to have learning difficulties.

Table 2. "Total use of ICT" for categories of learning difficulties. Students' replies.

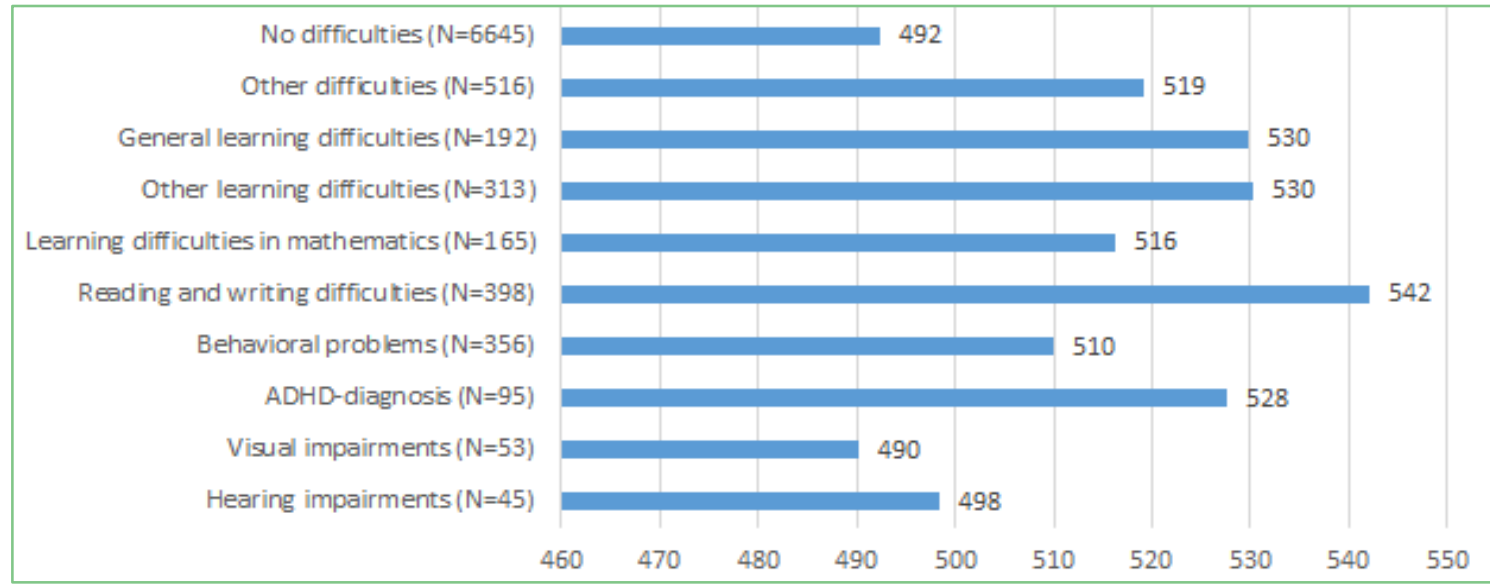

In Table 2, the results on the factor "total use of ICT", as reported by the students themselves, are shown for various groups of students. The score of students with no difficulties is 492, while the score of all "difficulty groups," except visual impairments, are higher. The highest score is from the group with reading and writing difficulties, 542 . This is 50 points $(0.5 \mathrm{SD})$ more than the group with no difficulties, which is a substantial difference. Below we will take a closer look at precisely the group with reading and writing difficulties compared to students without difficulties, when it comes to the subject Norwegian.

Table 3. How often is ICT used by students with learning and writing difficulties in the subject Norwegian? Student replies. Percentage.

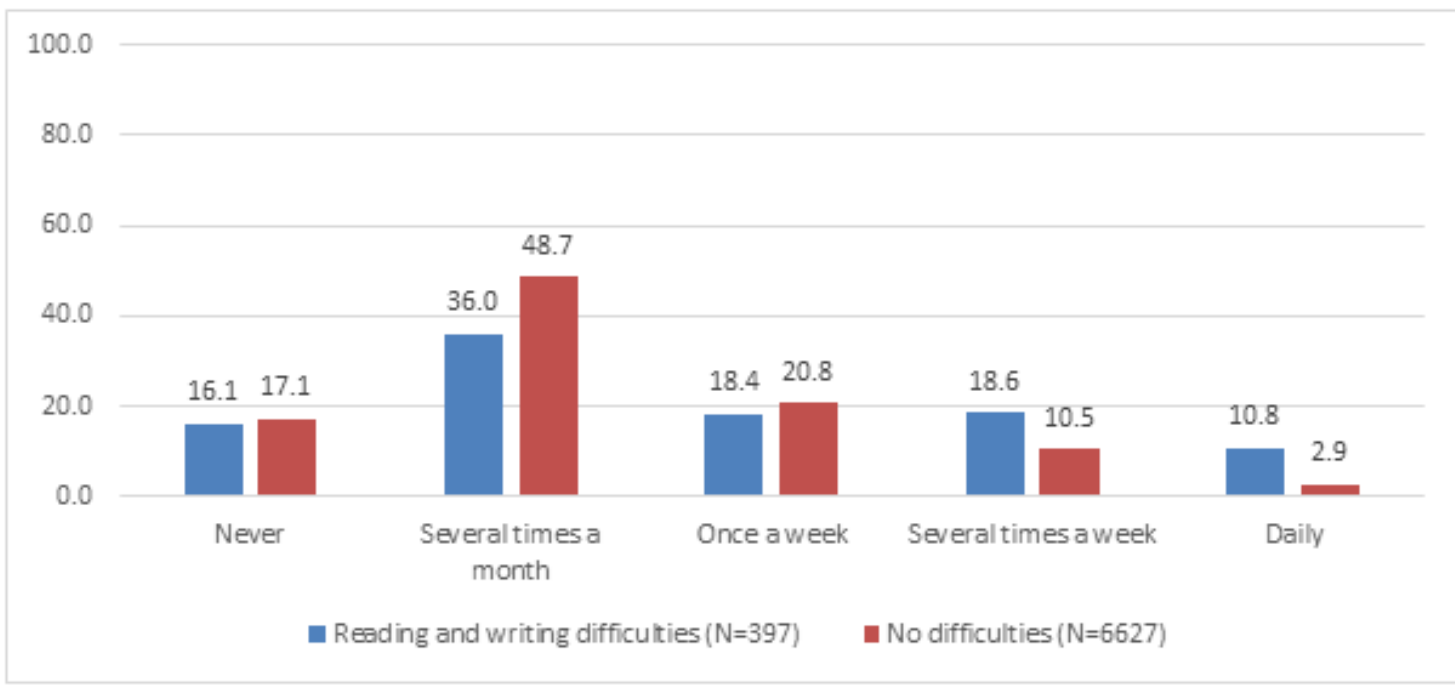

From this table we can see that $29,4 \%$ of students with reading and writing difficulties report using ICT daily or several 
times a week in the subject Norwegian, compared to $13,4 \%$ of students with no difficulties. More than half of the students with reading and writing difficulties $(52,1 \%)$ say that they rarely or never use ICT in this subject, if at all ("never" or "several times a month"). Two out of three students with no difficulties report that they rarely or never use ICT in this subject.

Observation data also helped in illuminating the extent of ICT use among the students with SEN. How many of the 5 minutes' interval observations revealed any ICT activity?

Table 4. The extent of ICT activity among students with SEN during the classroom observations.

\begin{tabular}{|c|c|c|}
\hline Total number of observations & Observations of students using ICT & Observations with ICT (\%) \\
\hline 7673 & 364 & 4,75 \\
\hline
\end{tabular}

We see above that less than $5 \%$ of all the observations include any use of ICT among the students with SEN. When we consider the number of students we are talking about - not the number of observations - we find that $36 \%$ of the students with SEN in primary schools used ICT once or more during the observation period, which was one whole day at school. For lower secondary school, the percentage was 28 , which means that the higher the age of the students, the less they used ICT. As to gender differences in ICT use, we found that boys generally tend to use the technology a bit more than girls, especially in the group with reading and writing difficulties, but the differences are relatively small.

\subsection{Academic Achievement and ICT Use}

In table 5 we compare the mean score on academic achievements for the group of students reporting frequent ICT-use with students reporting low-frequent ICT-use. The achievement level is assessed by the class teacher.

Table 5. Academic achievements. High- and low-frequency ICT users.

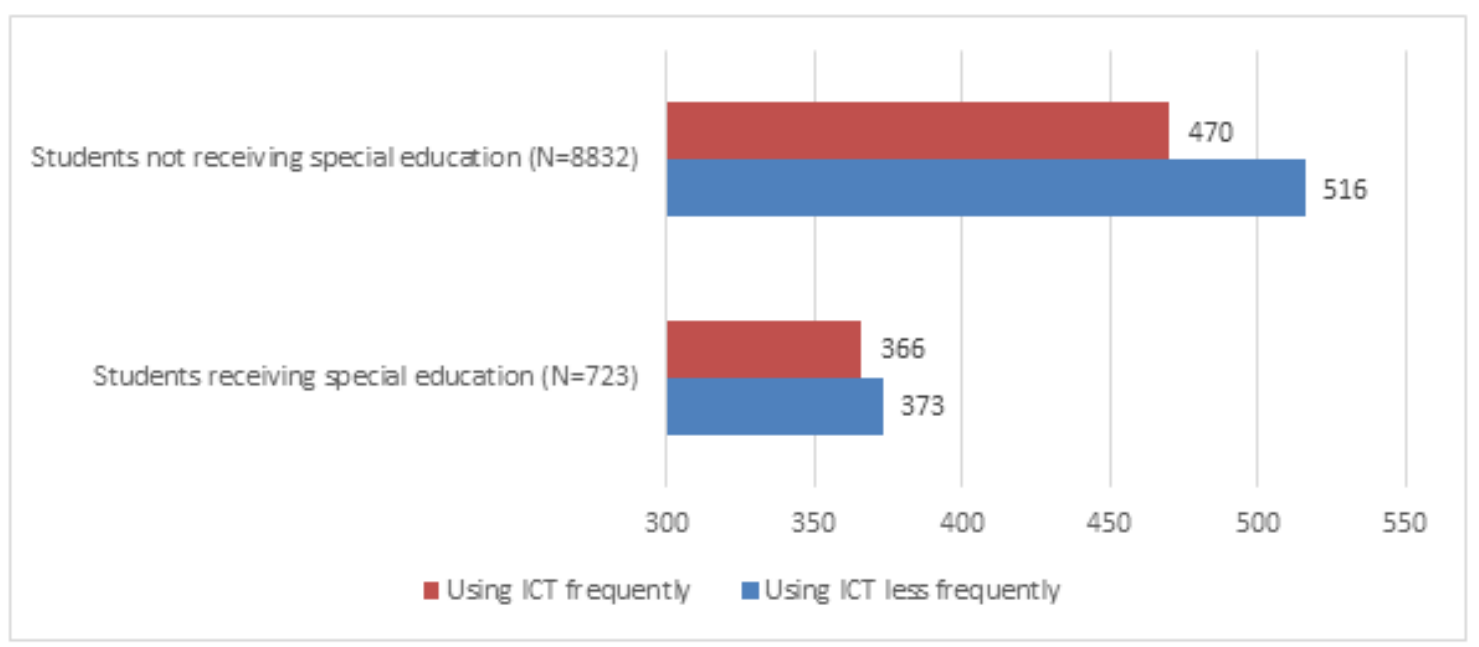

The table is split into two parts: students who do not receive special education (upper part) and students who receive special education (lower part). The analysis shows that for students without special education we find a significant difference (46 points) in favor of the low-frequency group, i.e. the higher achievement the less use of ICT. For students receiving special education the difference is only 7 points, or next to nothing.

\subsection{Teachers' and Students' View of the Affordances of ICT}

The following table shows how the students with SEN respond to three questions in the interview about computer use. 
Table 6. How do students with SEN regard using ICT? Percent.

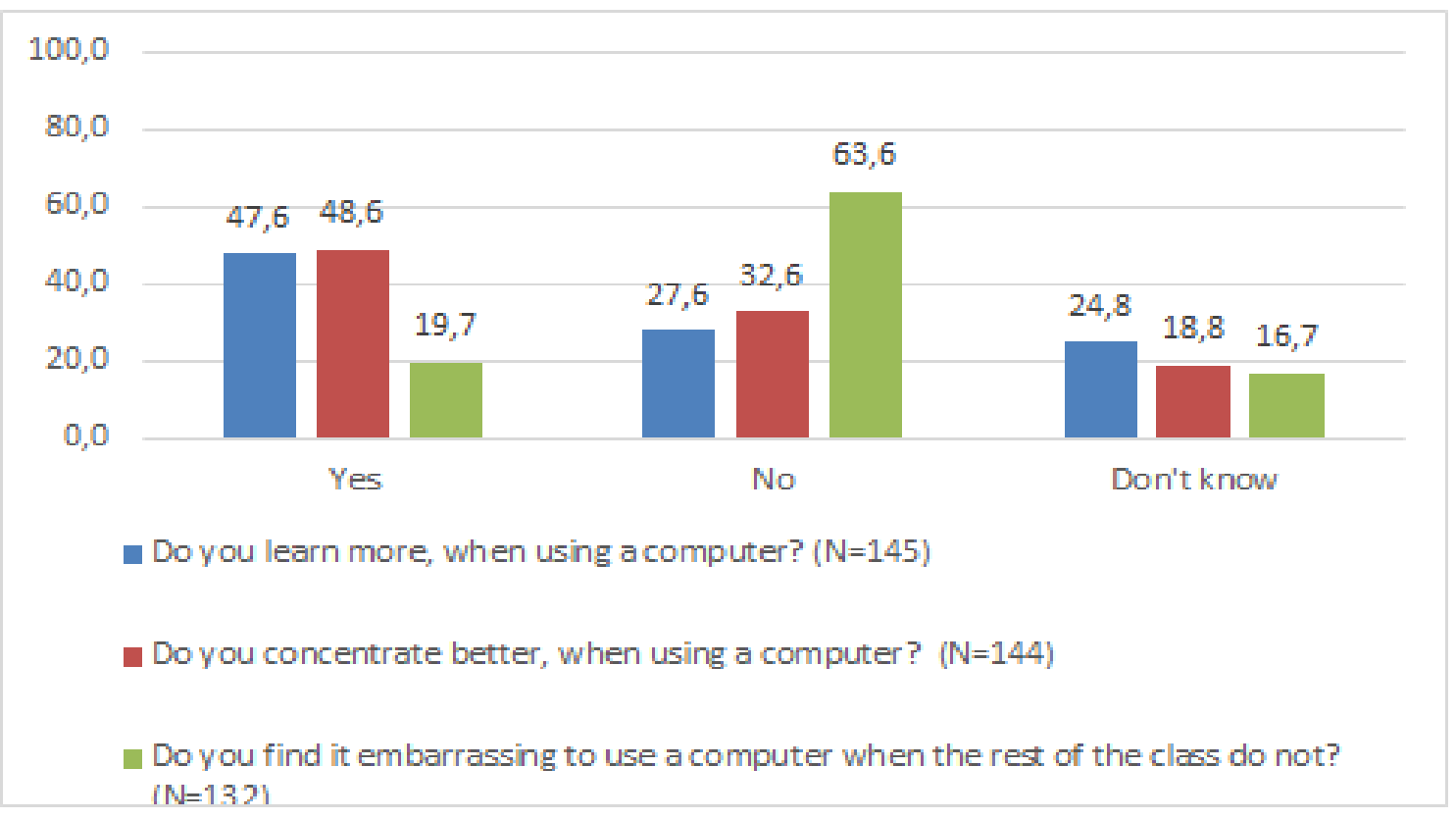

The answers in Table 6 show that almost half of the students with SEN feel they learn and concentrate better when using a computer. However, close to $20 \%$ - mostly girls - also find it embarrassing to use a computer if other students do not.

Turning to the teachers, we show below how two groups of teachers regard the affordances of ICT for their students with SEN. They responded to four statements about this in the interviews.

Table 7. How do teachers regard using ICT for students with SEN? Partly of fully agree, percent.

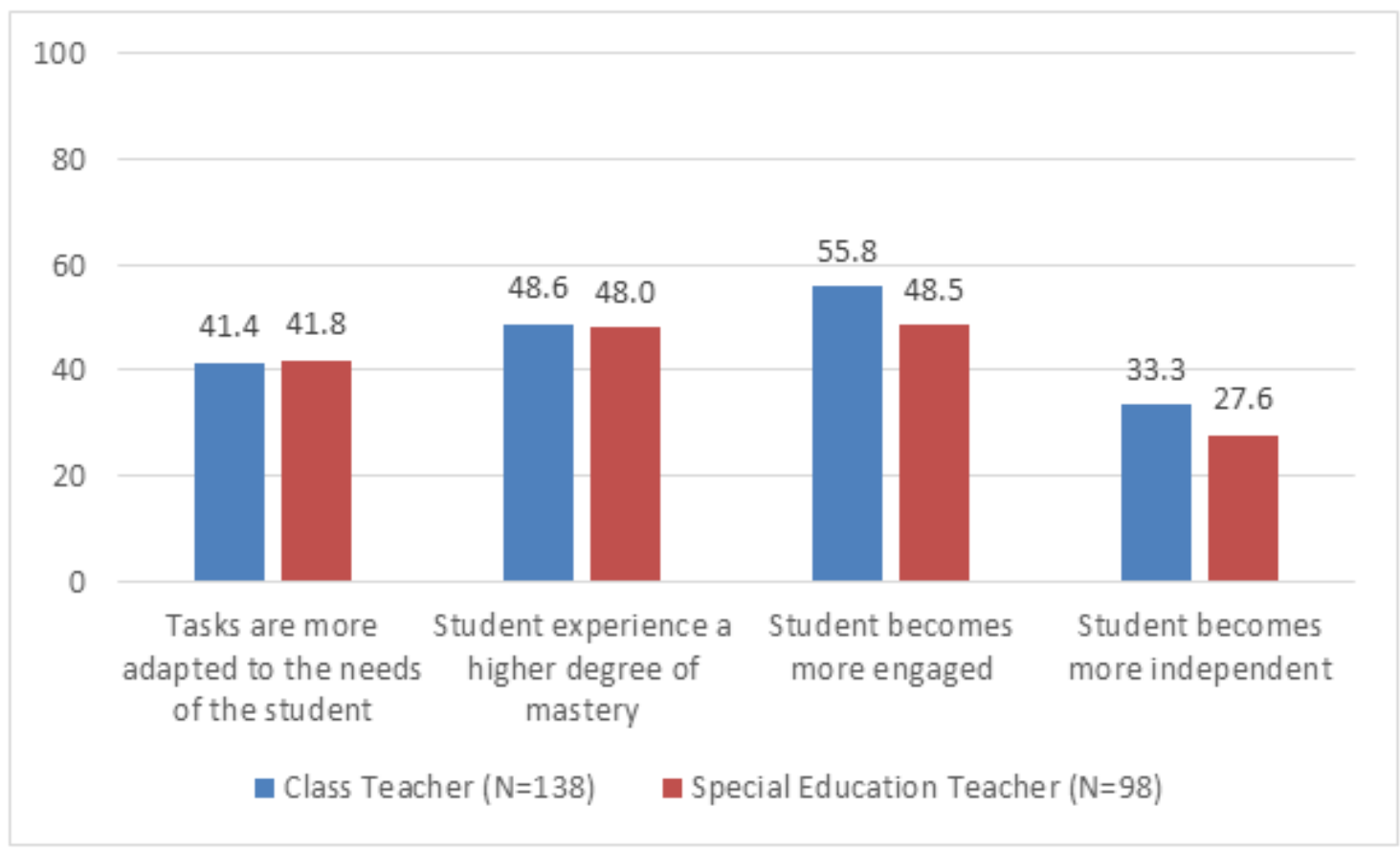

The numbers above show that generally a little less than half of the respondents express great enthusiasm about the affordances of ICT for the students with SEN. However, when split on students' difficulties (not shown in the table), we find that for students with reading and writing difficulties, teachers are far more supportive of the statements (about 70\% adherence). Moreover, when it comes to this group of students, special teachers clearly see more potential in ICT than class teachers do.

From the observation data, we see that when the trained special teachers are responsible for the special education lesson, the students use ICT more than with other staff in charge. When special education teachers were responsible for the 
special education lessons, twice as many observations of ICT use were made as when the class teacher or others were teaching. In the SPEED study, we found that less than half of special education lessons were given by teachers with special education training (45).

\subsection{Inclusion and Use of ICT}

Turning to indicators of inclusion, let us see how students identified as having SEN and their teachers score on our learning and participation factors. Comparisons are made with students without such needs. The participation factors of inclusion in this study are "social isolation" and "social relations", as operationalized in the questions cited in section 2.2.

Table 8. Inclusion as developing participation. Students' view of isolation and social relations.

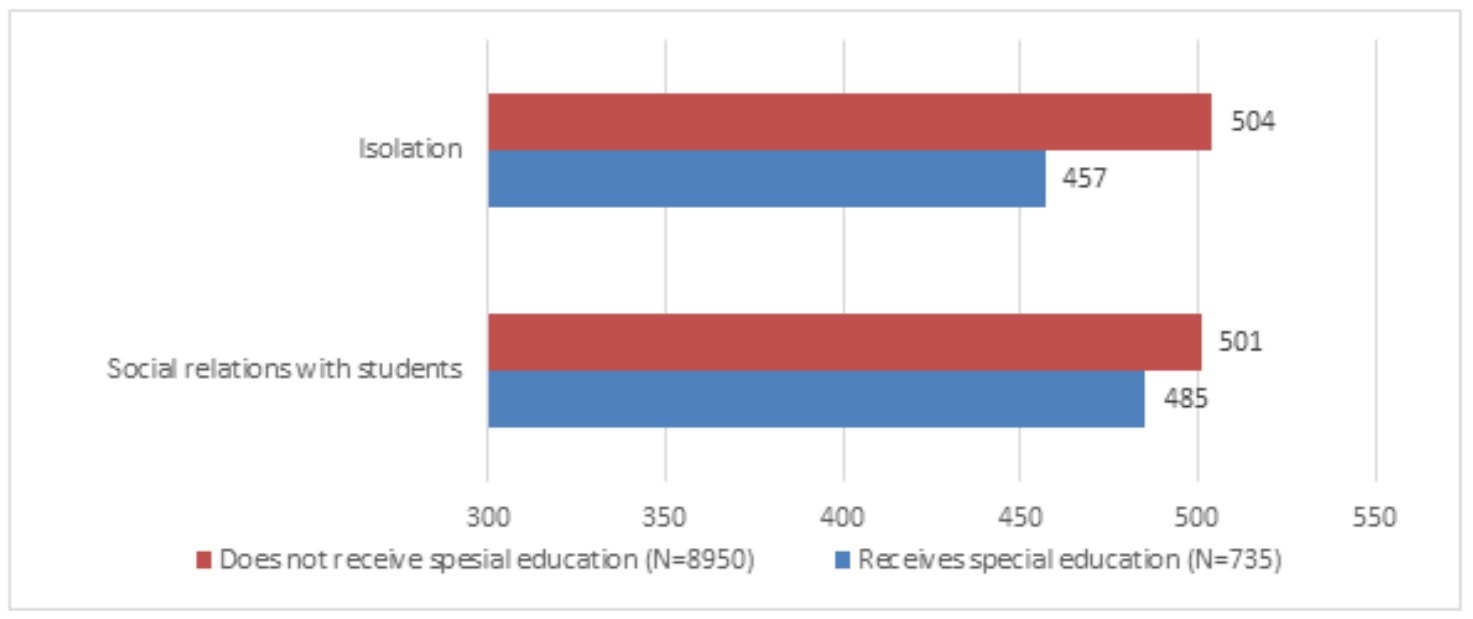

From the table above, we can see that students who receive special education feel more isolated in schools than their peers (47 points difference). However, when it comes to relations to other students in general, the difference between the two groups is small. This indicates that the students with SEN as a group feel reasonably well included in the peer group, although some are lonely and isolated.

Turning to inclusion in the learning perspective, let us look at what the class teachers say about their students in the survey.

Table 9. Inclusion as developing learning. Teachers'view of academic achievements and engagement for students with and without special education.

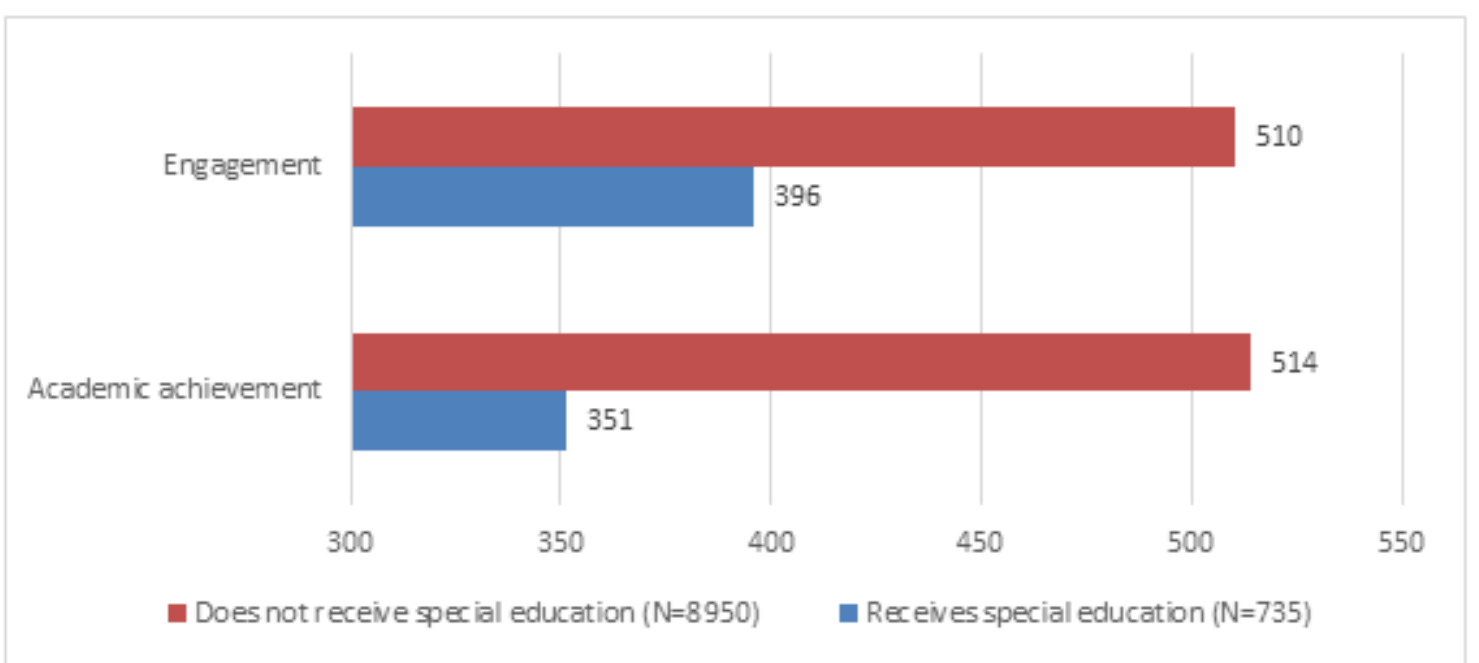

Not surprisingly, we see that teachers regard the academic achievements of students who receive special education as far below the rest. The standard deviation is more than 1.5 , which is a huge difference. However, there is also a considerable gap as to teacher perception of engagement in school work between the two groups of students, more than 1 SD.

In the two tables above, we have referred to inclusion indicators, but not to ICT. What part does such technology play in the inclusion efforts of the schools? Class teachers of students with SEN and their special teachers were asked in 
interviews whether ICT is seen as an obstacle.

Table 10. To what extent is use of ICT an obstacle to inclusion? Teachers' attitudes. Percent.

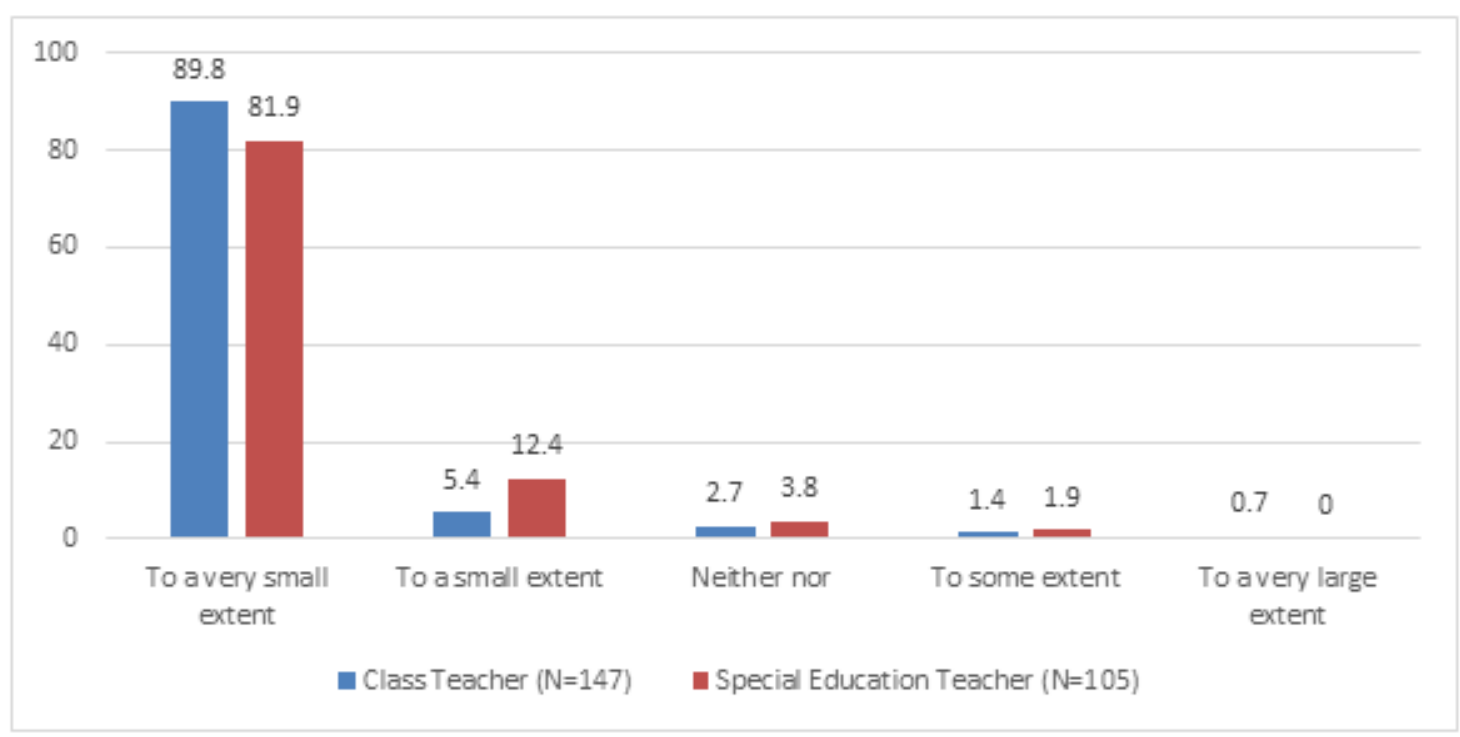

The findings in Table 10 show that very few teachers regard ICT to be a barrier to inclusion for the students with SEN; about $2 \%$ said to some or to a very large extent. A fair assumption is that most teachers do see ICT as supporting inclusion. For instance, 26 of a group of 29 special teachers in another part of the SPEED project noted that the use of ICT is helpful in increasing learning outcome for students with SEN. 21 of the 29 also said that ICT facilitates inclusive practices (46).

Special educational lessons in the subject Norwegian often constitute the core part of a student's special program. The student may also have regular lessons in Norwegian. The students with SEN who were observed using ICT reported far more than other students that they use ICT daily or several times a week in Norwegian $(40.5 \%)$, while the score of students without SEN is 9.9\%. These high-frequency ICT users tend to like the subject better than others. However, nearly half of our group of frequent ICT users ticked off in the survey that they never used ICT to present for the class. The "never" figures were $30 \%$ for other students with SEN and 20\% for students without SEN.

\section{Discussion}

To briefly summarize, before a more detailed discussion of results below, students with SEN use ICT more than other students, and in the subject Norwegian a great deal more. Students with literacy difficulties are the most frequent users of ICT. But generally, technology use in the lessons was modest for all students. Our data reveal few clear links between the use of ICT and inclusion, but there are some connections that we will comment on.

When our results show that digital learning is not very widespread, this is in accordance with other findings (24).
In the subject Norwegian where many students with SEN actually do use ICT a great deal, half of them never present anything electronically for their peers. This is not a promising result from an inclusion perspective, as it shows a lack of participation in the learning community in class. Despite this, students with SEN on average feel as socially included with their peers as other students do, even though more students with SEN report loneliness and isolation at school.

The results also reveal the striking fact that low-achieving students use ICT more than high-achieving students. Most students with SEN are part of the low-achieving group. However, there are no indications of a causal relationship suggesting that the less one uses ICT, the better his/her marks. Possible explanations are rather that although ICT is used extensively by some students, relatively speaking, it is perhaps not always used in ways that develop the digital skills for which the Norwegian curriculum calls. In the current debate in Norway, this is suggested $(47,48)$. Is ICT used for other things than targeted subject learning? For instance, the use of ICT for engagement or reward purposes is quite common ( $\mathrm{cf}(13$, 49)). This certainly applies to students with SEN as well, but their extended use of ICT is also about particular programs or technologies meant to compensate for their difficulties. Their achievements would have likely been even lower without the ICT support.

Although it is not unambiguous, the affordances of ICT for students who face particular challenges are well described in the literature ( $\mathrm{cf}(13,24))$. With this background in mind, our students with learning difficulties seem to use ICT far less than recommended, even if they use it more than their peers. Both students and teachers in our study are generally positive about the use of ICT, in particular digital reading and writing aids. What is the 
reason they do not use it more? In the SPEED material, we have little information to throw light on this. An English survey shows that special educators in grades 6 to 8 find that digital aids can be useful for students who struggle with reading and writing, but they usually do not actually use them much (50). According to another study, student teachers displayed very positive attitudes toward using ICT and to inclusive education, but slightly less positive attitudes toward e-inclusion (15). Practical obstacles to ICT use that are mentioned are, among others, that the technology is too expensive, that it is time consuming, it is difficult to use in teaching, it is difficult to use for the student and so on. But the most important explanation that is put forward, apart from cost, is that many teachers lack skills and need more education (50). This corresponds with several other studies (51-54). The lack of correspondence between positive attitudes toward ICT and actual use is also expressed in the ICILS study (55). Here too, the lack of expertise is seen as an important reason.

Specific knowledge in relevant digital technology is important for inclusion when particular groups of students are concerned. Broadly speaking, however, what kind of teacher competence is most important in an inclusive pedagogy? Florian (56) refers to four teaching strategies that are seen as helpful in promoting inclusive teaching: differentiation strategies, cooperative learning strategies, classroom management strategies, and social skills (57). Florian's own research identifies additional strategies as well, and the one most frequently mentioned by the teachers she asked was developing students' self-esteem and sense of belonging. In our data, we saw that class teachers seem to have much lower expectations of students with SEN than other students. Naturally, concerning many students with SEN, expectations concerning academic achievement will not be high compared to the group of students without SEN. However in theory, expectations in the subjects might be differentiated according to students' actual skills and abilities; hence the meaning of 'high expectations' would vary. What is more striking in our findings than low academic expectations is that expectations in a non-academic area in school such as student engagement are so low. When is a student motivated or engaged? For instance, two of the engagement questions in our study were about 'interest in learning in the lessons' and 'efforts during lessons'. Engagement then is a function of what is going on in the lessons. Any student - with or without SEN - could display interest \& efforts if what is taught feels relevant and how it is taught takes into account strengths and weaknesses the learner might have. A source of self-esteem is when the learner is able to meet the expectations; hence lessons which communicate adequate expectations have the potential to be supportive of the students' self-esteem.

We see in our study that many students with SEN use ICT a great deal in the subject Norwegian. They are reporting to like the subject better than other students do, probably implying that they are more dedicated and benefit more as well ( $(\mathrm{cf}(29))$. In these lessons the students would appear as motivated, but the teacher who answered in the survey either was not aware of this or did not include these observations in the general impression of the child.

One out of 5 students with SEN in our data felt stigmatized when using a computer if others did not use it. Stigmatization is not helpful in developing self-esteem either. This pitfall will be avoided if all learners are using a range of methods and technologies, including computers. Such a strategy - universal design for learning - is recommended for instance by $(13,58)$. Keywords are variation and flexibility in teaching and learning strategies in the class. In addition, individual adaptation of assistive technology will be needed for some as well, but the stigma by using it will lessen if there is a basic level of universal design for learning.

The crucial point is not only how much digital technology is used, but how it is used. To use it adequately in education, the teachers' digital competency is the key factor, in our case particularly the competence in using ICT in special education or in teaching other learners who struggle. We assume that when the best-qualified teachers use ICT more, this is due to better digital qualifications, and that better qualified teachers support children's learning in a more professional way. The latter is shown by many writers, for instance Egelund et al. (59). In our data, we see that trained special educators use ICT in their teaching more often than other staff. But special education in Norway is not always given by the best qualified staff; only in half of the special education lessons observed in the SPEED project was the special educator in charge. Pairing the competent special educator and the child who has a statement of special needs has the potential of increasing learning.

In teacher education and in in-service training, the students/ teachers need to meet and become comfortable with some artefacts and programs within ICT to be able to analyze the affordances and limitations for their own teaching. The European Agency for Special Needs and Inclusive Education (26) has been looking into ICT for inclusion in several European countries. One strong recommendation from them is that the training of educational staff in the use of general and specialist ICT must be considered a priority area. This brings us to a state or systems level, while our research has been dealing with teacher and student experiences. But inclusion challenges the cultures, policies and practices on several levels, from the individual student to teacher education and overarching values as well as national policies; see Table 11 below (cf (44)). On each level, issues of developing participation and learning will need attention. We have listed some examples, a few of them with a question mark. Our inquiry has been on levels 1 and 2 , and we believe that increasing research-based knowledge of what is happening on these levels will inform decisions on upper levels. And reversely, decisions on upper levels strongly influence daily school life for teachers and students. 
Table 11. Levels of inclusion. Examples of barriers and support to inclusive ICT in Norwegian schools.

\begin{tabular}{|c|c|c|}
\hline \multicolumn{3}{|c|}{ Inclusion as developing learning and participation in schools } \\
\hline Levels of inclusion & BARRIERS to inclusive ICT & SUPPORT of inclusive ICT \\
\hline $\begin{array}{c}\text { 5. STATE level: Values, ideologies and } \\
\text { policies. Teacher education. }\end{array}$ & $\begin{array}{c}\text { Does teacher education emphasize issues } \\
\text { of ICT and inclusion sufficiently? }\end{array}$ & $\begin{array}{c}\text { Legal rights and inclusion ideology are } \\
\text { in place. }\end{array}$ \\
\hline $\begin{array}{c}\text { 4. MUNICIPALITY/school owner level: } \\
\text { Organization \& economy. }\end{array}$ & $\begin{array}{c}\text { Does in service training give priority to } \\
\text { e-inclusion pedagogy? }\end{array}$ & $\begin{array}{c}\text { Investments in technology are } \\
\text { relatively high. }\end{array}$ \\
\hline 3. SCHOOL level & $\begin{array}{c}\text { Sufficient teacher competence regarding } \\
\text { ICT and inclusion is not widespread. }\end{array}$ & $\begin{array}{c}\text { The access to relevant hardware and } \\
\text { software is usually quite good. }\end{array}$ \\
\hline $\begin{array}{c}\text { 2. CLASSROOM level: } \\
\text { Teaching and learning }\end{array}$ & $\begin{array}{c}\text { Teachers' expectations to the engagement } \\
\text { and learning of students with SEN are low. } \\
\text { Potentials for teaching and learning with } \\
\text { ICT are underused. }\end{array}$ & $\begin{array}{c}\text { Sometimes ICT is used to engage } \\
\text { students and remove barriers to } \\
\text { learning and participation. }\end{array}$ \\
\hline $\begin{array}{c}\text { 1. STUDENT level: } \\
\text { Does the student learn and participate? }\end{array}$ & $\begin{array}{c}\text { Students with SEN sometimes feel } \\
\text { stigmatized using ICT. }\end{array}$ & $\begin{array}{c}\text { Students with SEN feel socially } \\
\text { relatively well included. }\end{array}$ \\
\hline
\end{tabular}

\section{Conclusions}

Our main intention with this study has been to explore the relationship between ICT and inclusion for students seen to have some sort of difficulty in school. Our first research question was: To what extent is ICT in any form used by students with learning difficulties?

Findings indicate that digital learning is neither very widespread in regular nor in special education. However, students receiving special education on average use ICT more than other students, particularly in the subject Norwegian. The teachers and students in question generally treasure the affordances of ICT, as do many experts, so there is probably a much greater potential still for supporting learning and participation by using ICT for students who struggle.

The second research question was whether ICT is seen to support inclusion for students with SEN. According to our data, there are few indications that ICT plays a distinct part in either supporting or preventing inclusion. Generally, compared with students without SEN on our inclusion indicators, we see that when experiences of participation are concerned, the students with SEN answer that they feel almost as accepted and involved in a social fellowship as other students. However, it is worth noting that there are clearly more students with SEN than others who see themselves as isolated at school. Preventing socially exclusionary mechanisms - and addressing them if they occur-is an important aspect of an inclusive pedagogy. Creating such a climate in class can be seen as part of the notion e-inclusion (18).

Looking at inclusion as developing learning, class teachers' view of the students with SEN is not so inclusive, since these teachers seem to have much lower expectations towards students who receive special education than to other students. The effect of teacher expectations on learning is well known (cf 60, 61). The subject Norwegian is an exception in our material; here we see a likely direct link between frequent ICT use and improved engagement and learning. This is a rare case in our material of a reasonably clear positive connection between ICT and inclusion.

A negative relationship between ICT and inclusion is also identified in our results: approximately $20 \%$ of the students with SEN say that they feel stigmatized using a computer if they are the only ones doing it. Stigmatization processes will affect self-esteem and learning negatively, thus undermining inclusion (62). To avoid such a situation, we recommend a universal learning design, implying in the case mentioned above that all students use computers, not just the students with SEN (13). It is promising that the Norwegian government in a recent white paper suggests a demand for digital learning tools to be universal (63).

Still, some students with learning difficulties or disabilities will always profit from additional, individually adapted assistive ICT, as long as stigmatization is minimized and teacher competence is high. We see that when well-qualified teachers are responsible for special education, ICT is used more, but only about half of the teachers in charge of special education have further education in special education. Even many of those who have relevant qualifications probably possess limited insight into ICT as part of an inclusive pedagogy. So, our other recommendations are to improve preservice and in-service teacher education in these matters $(\mathrm{cf}(15,26))$ and to match students with SEN in schools with highly competent staff, as there seems to be a mismatch between access to technology and teacher competence in using it. The government proposes that knowledge about ICT for students with SEN has to be disseminated (66), which is 
good, but it remains to be seen how and when.

\section{Acknowledgements}

This work was supported by The Research Council of Norway under grant number 218326.

\section{REFERENCES}

[1] The Norwegian Directorate for Education and Training. Utdanningsspeilet 2017. Tall og analyse av barnehager og grunnopplæringen i Norge 2017 [cited 2017 30.11]. Available from: http://utdanningsspeilet.udir.no/2017/.

[2] The Norwegian Ministry of Education. Kvalitet i skolen Oslo: Norwegian Ministry of Education; 2008 [23.02.2015]. Available from:

https://www.regjeringen.no/nb/dokumenter/stmeld-nr-31-2 007-2008-/id516853/?docId=STM200720080031000DDD EPIS\&ch $=1 \& \mathrm{q}=\mathrm{kvalitet} \% 20 \mathrm{i} \% 20$ skolen $\&$ redir=true\&ref $=\mathrm{s}$ earch\&term $=$ kvalitet $\% 20 \mathrm{i} \% 20$ skolen.

[3] The Norwegian Ministry of Education. Meld. St. 18 (2010-2011) Report to the Storting (white paper) Summary Oslo: Norwegian Ministry of Education; 2011. Available from:

http://www.statped.no/Global/Publikasjoner/Learning\%20t ogether\%20white\%20paper\%20Meld.\%20St.\%2018\%2020 102011.pdf.

[4] Haug P. Kva spesialundervisning handlar om, og kva funksjon den har. In: Haug P, editor. Spesialundervisning, innhald og funksjon. Oslo: Samlaget; 2017. p. 386-411.

[5] Nes K. The first decade of the 21st century: A backlash for inclusion in Norwegian schools? Zeitschrift für Inklusion-onlinenet. 2010; 2

[6] The Norwegian Directorate for Education and Training. Equity in Education for all - understanding central concepts 2008 [cited 2015 24.02]. Available from: http://www.udir.no/Upload/Brosjyrer/5/Likeverdig_eng_jan $\% 202008$.pdf.

[7] The Norwegian Ministry of Education. Læreplanverket for Kunnskapsløftet 2006 [cited 2017 30.11]. Available from: https://www.udir.no/laring-og-trivsel/lareplanverket/.

[8] Lerner JW, Johns B. Learning disabilities and related mild disabilities: Cengage Learning; 2011.

[9] UNESCO. A guide for ensuring inclusion and equity in education. Paris: UNESCO; 2017 [cited 2017 30.11]. Available from:

http://unesdoc.unesco.org/images/0024/002482/248254e.pd f.

[10] Booth T, Ainscow M. Index for Inclusion: Developing learning and participation in schools. 3 ed. Bristol: Center for Studies on Inclusive Education (CSIE); 2011.

[11] Hansen O, Qvortrup L. Inclusion i Danmark-hvilke konsekvenser har begrebsdefinitioner for den paedagogiske praksis. Paideia, Tidsskrift for professionel paedagogisk praksis. 2013; 5(13):8-19.

[12] Alexander R. Still no pedagogy? Principle, pragmatism and compliance in primary education. Cambridge Journal of Education. 2004; 34(1):7-33.

[13] Edyburn DL, Rao K, Hariharan P. Technological Practices Supporting Diverse Students in Inclusive Settings. The Wiley Handbook of Diversity in Special Education. 2017:357-77.

[14] Florian L, Hegarty J. ICT and Special Educational Needs: a tool for inclusion: McGraw-Hill Education (UK); 2004.

[15] Beacham N, McIntosh K. Student teachers' attitudes and beliefs towards using ICT within inclusive education and practice. Journal of Research in Special Educational Needs. 2014; 14(3):180-91

[16] Brodin J. Can ICT give children with disabilities equal opportunities in school? Improving Schools. 2010; 13(1):99-112.

[17] Florian L. Uses of technology that support pupils with special educational needs. ICT and special educational needs: A tool for inclusion. 2004:7-20.

[18] Abbott C. E-inclusion: Learning difficulties and digital technologies: Futurelab Bristol; 2007.

[19] Josjö H. ICT and inclusion: Teachers' perceptions on the use of information and communication technology for students with special educational needs in general educational settings. 2013.

[20] Fasting RB. IKT-basert læringsstøtte for elever med lese- og skrivevansker. Spesialpedagogikk. 2008; 73(7):61-75.

[21] WHO. Disabilities and rehabilitation World Health Organization; 2014 [cited 2014 21.11]. Available from: http://www.who.int/disabilities/technology/en/.

[22] Söderström S. Teknologibruk i den digitale enhetsskolen: en pilotstudie av bruk av informasjons- og kommunikasjonsteknologi (IKT) i skolehverdagen for grunnskoleelever med nedsatt funksjonsevne. Trondheim: NTNU samfunnsforskning, Avdeling for mangfold og inkludering; 2010. 60 s. p.

[23] Krumsvik RJ. Skulen og den digitale læringsrevolusjonen. Oslo: Universitetsforl; 2007. 276 s. p.

[24] Egeberg G, Björk Gudmundsdottir G, Hatlevik OE, Ottestad G, Skaug JH, Tømte K. Monitor 2011 - The Digital State of Affairs in Norwegian Schools. Nordic Journal of Digital Literacy. 2012; 7(01).

[25] Brøyn T, Schultz J-H. IKT og tilpasset opplæring. Oslo: Universitetsforl.; 2005.

[26] European Agency for Development in Special Needs Education. Information and Communication Technology for Inclusion: Developments and Opportunities for European Countries European Agency for Development in Special Needs Education (EADSNE), 2013

[27] Lupton D, Seymour W. Technology, selfhood and physical disability. Soc Sci Med. 2000; 50(12):1851-62.

[28] Pape TL-B, Kim J, Weiner B. The shaping of individual meanings assigned to assistive technology: a review of 
personal factors. Disability and rehabilitation. 2002;24(1-3):5-20.

[29] Svendsen HB. Et inkluderende didaktisk design? Afprøvning af et didaktisk design målrettet elever med og $\mathrm{i}$ skriftsprogsvanskeligheder, der anvender læse-og skriveteknologi. Studier i læreruddannelse og-profession.2(1):90-116.

[30] Topphol A, Haug P, Nordahl T. SPEED-prosjektet, metode, datagrunnlag og prosedyrar. Spesialundervisning, innhald og funksjon (pp X-Y) Oslo: Det Norske Samlaget. 2017

[31] Eccles JS, Midgley C. Stage-environment fit: Developmentally appropriate classrooms for young adolescents. Research on motivation in education. 1989; 3:139-86.

[32] Eccles JS, Midgley C, Wigfield A, Buchanan CM, Reuman D, Flanagan C, et al. Development during adolescence: The impact of stage-environment fit on young adolescents experiences in schools and in families. American psychologist. 1993; 48(2):90.

[33] Trickett RME. The classroom environment scale. California: Consulting psychology press; 1974.

[34] Ogden T. Kompetanse i kontekst: en studie av risiko og kompetanse hos 10-og 13-åringer: Barnevernets utviklingssenter; 1995.

[35] Nordahl T, Sørlie M. Brukerperspektiv på skolen: elever og foreldre om skole og relasjoner: delrapport 3 fra forskningsprosjektet" Skole og samspillsvansker"(Vol. 12d/98). Oslo: Norsk institutt for forskning om oppvekst, velferd og aldring. 1998

[36] Nordahl T. En skole-to verdener: et teoretisk og empirisk arbeid om problematferd og mistilpasning $\mathrm{i}$ et elev-og lærerperspektiv: Norsk institutt for forskning om oppvekst, velferd og aldring; 2000.

[37] Nordahl T. Læringsmiljø og pedagogisk analyse: en beskrivelse og evaluering av LP-modellen (Vol. 2005: 19). Oslo: Norsk institutt for forskning om oppvekst, velferd og aldring. 2005.

[38] Sørlie M-A, Nordahl T. Problematferd i skolen: hovedfunn, forklaringer og pedagogiske implikasjoner: hovedrapport fra forskningsprosjektet" Skole og samspillsvansker: Norsk institutt for forskning om oppvekst, velferd og aldring, NOVA; 1998

[39] Hatlevik O, Egeberg G, Guðmundsdóttir G, Loftsgarden M, Loi M. Monitor skole 2013: Om digital kompetanse og erfaringer med bruk av IKT i skolen. Senter for IKT i Utdanningen. 2013.

[40] Skaalvik E. Motivasjonsskala: NTNU, Pedagogisk institutt; 1993.

[41] Gresham FM, Elliott SN. Social skills rating system: Manual: American Guidance Service; 1990.

[42] Powell J, Martindale A, Kulp S. EVALUATION OF TIME-SAMPLE MEASURES OF BEHAVIOR. Journal of Applied Behavior Analysis. 1975;8(4):463-9.

[43] Haug P. Kvalitet i opplæringa: Arbeid i grunnskulen observert og vurdert. Oslo: Samlaget; 2012.
[44] Haug P. Er inkludering i skulen gjennomførleg? . In: Germeten S, editor. De utenfor: Forskning om spesialpedagpogikk og spesialundervisning. Bergen: Fagbokforlaget; 2014. p. 15-38

[45] Haug P. Spesialundervisning i praksis. Paideia - Tidsskrift for profesjonell pedagogisk praksis $2014 ; 8$.

[46] Mølster T. IKT for elevar med spesifikke lese- og skrivevanskar. Spesialundervisning - Innhald og funksjon: Det Norske Samlaget; 2017. p. 235-55.

[47] Vavik L. Skolefagsundersøkelsen 2009: utdanning, skolefag og teknologi. Stord: Høgskolen Stord/Haugesund; 2010. 279 s.: ill. p.

[48] Krumsvik RJ, Egelandsdal K, Sarastuen NK, Jones LØ, Eikeland OJ. Sammenhengen mellom IKT-bruk og læringsutbytte (SMIL) i videregående opplæring sluttrapport 2013 [cited 2014 08.10.2014]. Available from: http://www.ks.no/PageFiles/41685/Sluttrapport_SMIL.pdf.

[49] Nes K, Wikan G, editors. Interactive whiteboards as artefacts to support dialogic learning spaces in primary schools. Seminar net; 2017.

[50] Flanagan S, Bouck EC, Richardson J. Middle School Special Education Teachers' Perceptions and Use of Assistive Technology in Literacy Instruction. Assistive Technology. $2013 ; 25(1): 24-30$

[51] Horne P-L. Bruk av datahjelpemidler for elever med dysleksi. Stord: Høgskolen Stord/Haugesund; 2012. Available from:

https://brage.bibsys.no/xmlui/bitstream/handle/11250/1522 99/P\%C3\%A51\%20Lennart\%20Horne.pdf?sequence=1.

[52] Høigaard B, Svestad PJ, Landmark E. Pedagogisk bruk av IKT: Har skolene og lærerne den nødvendige kompetansen? Utdanning. 2010;17:44-5.

[53] Olsson E, Larsson A-K, Reneland-Forsman L, Karlsudd P. Alternativa verktyg för elever i läs- \&amp; skrivsvårigheter och dyslexi: En förlängd arm i lärandet? 2012

[54] Tallay E, Romnes G. IKT for dyslektikere: hvordan blir datamaskiner som formidles gjennom Hjelpemiddelsentral brukt i skolen? Universitetet i Oslo ,2007.

[55] Throndsen I, Gudmundsdottir GB, Hatlevik OE, Loi M, Rohatgi A, Olsen RV. Læring av IKT. Elevenes digitale ferdigheter og bruk av IKT i ICILS 2013. Universitetsforlaget; 2015.

[56] Florian L, Hick P, Kershner R, Farrell P. Towards inclusive pedagogy. Psychology for inclusive education: New directions in theory and practice. 2009:38-51.

[57] Scott BJ, Vitale MR, Masten WG. Implementing instructional adaptations for students with disabilities in inclusive classrooms: A literature review. Remedial and Special Education. 1998;19(2):106-19.

[58] Gordon N, Meyer, A, Rose, DH. Universal Design for Learning: Theory and Practice. 1st Edition. CAST professional Publishing, Boston. 2014.

[59] Egelund N, Tetler S, Andersen GL, Dyssegaard C, Persson B. Effekter af specialundervisningen : Pædagogiske vilkår i komplicerede læringssituationer og elevernes faglige, sociale og personlige resultater. 2009. København: 
Danmarks Pædagogiske Universitetsforl.

[60] Rosenthal R, Jacobson L. Pygmalion in the classroom: Teacher expectation and pupils' intellectual development: Holt, Rinehart \& Winston; 1968.

[61] Bandura A, Barbaranelli C, Caprara GV, Pastorelli C. Self efficacy beliefs as shapers of children's aspirations and career trajectories. Child development. 2001; 72(1):187-206
[62] Florian L. Towards inclusive pedagogy. Psychology for inclusive education: New directions in theory and practice. 2009:38-51.

[63] The Norwegian Ministry of Education. Framtid, fornyelse og digitalisering Oslo 2017 [cited 2017 29.11.]. Available from:

https://www.regjeringen.no/no/dokumenter/framtid-fornyel se-og-digitalisering/id2568347/. 